Agro-Science Journal of Tropical Agriculture, Food, Environment and Extension Volume 19 Number 1 (January 2020) pp. $11-17$

ISSN 1119-7455

\title{
EVALUATION OF YIELD AND YIELD RELATED TRAITS OF EXOTIC GRAIN AMARANTH (Amaranthus spp.) ACCESSIONS
}

\author{
${ }^{* 1}$ Idowu-Agida O.O., ${ }^{1}$ Oladosu B.O. and ${ }^{2}$ Olaniyi J.O. \\ ${ }^{1}$ Vegetable Improvement Programme, National Horticultural Research Institute, Ibadan, Nigeria \\ ${ }^{2}$ CPS Department, Ladoke Akintola University of Technology, Ogbomoso, Nigeria \\ *Corresponding author's email: agidadayo@gmail.com
}

\begin{abstract}
Amaranth grain yield varies widely in response to environment, weather conditions, species, genotype and production techniques. With appropriate varieties, yields of grain amaranth can be improved. The objective of this study was to assess the extent of yield variability in exotic grain amaranth accessions between locations. Field trials involving 28 accessions as treatments were conducted at two locations namely the Vegetable Research Farm of the National Horticultural Research Institute (NIHORT), Idi-Ishin Ibadan and the Teaching \& Research Farm of Ladoke Akintola University of Technology (LAUTECH), Ogbomoso. The two locations are in Oyo State, South-West, Nigeria, with Ibadan typifying Forest-Savanna transition zone and Ogbomoso Derived Savanna zone. The field trials were undertaken from August to December 2013. The 28 accessions were replicated three times in a randomized complete block design in each location. Data were collected on growth and yield parameters; inflorescence length, inflorescence weight, 1000-grain weight, grain production efficiency, and grain yield. Variability existed among the accessions of grain amaranth. There were significant $(p<0.05)$ differences in grain yield of the accessions. Accessions 74-43, RRC1351, RRC399, RRC8 and RRC551 (all of which are Amaranthus Caudatus spp.) produced higher grain yields in both locations compared to the rest of the accessions. The top high-yielding accessions included RRC1351

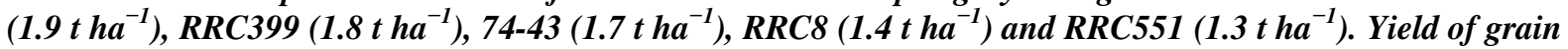
amaranth was significantly lower in the more humid Ibadan than the less humid Ogbomoso.
\end{abstract}

Key words: grain production efficiency, inflorescence length, weight and location

\section{INTRODUCTION}

Often times exotic accessions of vegetable crops outperform local ones (Oraegbunam et al., 2016). Amaranth belongs to the genus Amaranthus of the family Amaranthaceae. Nigeria is regarded as the center of diversity for Amaranthus spp. (Dulloo and Engles, 2003). Morphological characters are needed to describe plant growth habit and inflorescence characteristics (Kurlovich, 1998), and are influenced by consumer's preference, socio-economic status and natural selection (Ghafoor et al., 2001). Amaranthus shows a wide range in yield diversity within certain species (Grubben, 2004). Current interest in amaranths resides in the fact that they have high nutritional value due to higher amount of protein with balanced essential amino acid contents, (Gamel et al., 2004; Mnkeni et al., 2007). Stable genotypes are particularly needed in Nigeria where amaranths are grown under varied environmental conditions (Dulloo and Engles, 2003).

Amaranth shows a wide variety of morphological diversity within its certain species. They have broad genetic variability in plant type (erect to prostate), number of inflorescences (one to several), seed colour, earliness, protein content, plant height, seed and green matter yield, resistance to pest and diseases and adaptability to $\mathrm{pH}$, climate, rainfall and day length (Jacobsen et al., 2001). Genotypic and species differences in yield and yield attributes have been documented in amaranths (Vijayakumar, 1980; Campbell and Abbott, 1982). Therefore, the current research was to assess the extent of yield variability existing among 28 grain amaranth accessions for vegetable crop improvement.

\section{MATERIALS AND METHODS}

Field trials were conducted from August to December late cropping season 2013 in two locations. They are the Vegetable Research Farm of the National Horticultural Research Institute (NIHORT), Idi-Ishin, Ibadan ( $3^{\circ} 56^{\prime} \mathrm{E}$ and $7^{\circ} 33^{\prime} \mathrm{N}$; $168 \mathrm{~m}$ above sea level) within the Forest-Savanna transition agro-ecology and Teaching \& Research Farm, Ladoke Akintola University of Technology (LAUTECH), Ogbomoso (4० $10^{\prime} \mathrm{E}$ and $8^{\circ} 10^{\prime} \mathrm{N}$; $275 \mathrm{~m}$ above sea level) within the Derived Savanna agro-ecology of Nigeria. Monthly rainfall, temperature and relative humidity for the two experimental sites in 2013 are presented in Table 1. 
Table 1: Mean monthly temperature, relative humidity and rainfall of Ibadan and Ogbomoso 2013 cropping seasons

\begin{tabular}{|c|c|c|c|c|c|c|c|c|}
\hline \multirow[t]{2}{*}{ Month } & \multicolumn{4}{|c|}{ Ibadan } & \multicolumn{4}{|c|}{ Ogbomoso } \\
\hline & $\begin{array}{c}\text { Max Temp } \\
{ }_{\text {○ }}\end{array}$ & $\begin{array}{c}\text { Min Temp } \\
{ }_{\mathrm{C}}^{\circ}\end{array}$ & $\begin{array}{l}\mathrm{RH} \\
(\%)\end{array}$ & $\begin{array}{l}\text { Rainfall } \\
(\mathrm{mm})\end{array}$ & $\underset{\mathrm{C}}{\operatorname{Max}}$ & $\begin{array}{c}\text { Min Temp } \\
{ }_{\mathrm{C}}^{\circ}\end{array}$ & RH (\%) & $\begin{array}{l}\text { Rainfall } \\
\text { (mm) }\end{array}$ \\
\hline Jan & 33.6 & 22.1 & 87 & 00 & 35.1 & 22.6 & 73 & 00 \\
\hline Feb & 34.6 & 24.2 & 88 & 00 & 36.7 & 22.8 & 73 & 41 \\
\hline Mar & 34.4 & 24.1 & 89 & 208 & 34.9 & 23.1 & 76 & 439 \\
\hline Apr & 33.1 & 23.4 & 87 & 237 & 34.2 & 23.6 & 81 & 103 \\
\hline May & 31.5 & 23.0 & 88 & 150 & 31.2 & 22.8 & 85 & 157 \\
\hline Jun & 30.8 & 23.0 & 89 & 141 & 30.7 & 22.6 & 87 & 167 \\
\hline Jul & 29.5 & 23.0 & 91 & 98 & 28.5 & 21.3 & 91 & 77 \\
\hline Aug & 28.2 & 22.6 & 89 & 28 & 28.2 & 21.5 & 94 & 88 \\
\hline Sep & 29.9 & 22.4 & 92 & 215 & 29.2 & 21.5 & 89 & 117 \\
\hline Oct & 30.2 & 24.8 & 92 & 136 & 30.3 & 21.5 & 88 & 109 \\
\hline Nov & 32.1 & 22.1 & 91 & 113 & 31.8 & 21.8 & 83 & 145 \\
\hline Dec & 34.5 & 23.1 & 89 & 00 & 33.5 & 20.7 & 70 & 0.0 \\
\hline Mean & 31.87 & 23.15 & 89 & 111 & 32.0 & 22.2 & 83 & 12 \\
\hline
\end{tabular}

Ibadan climate data sourced from NIHORT Metrological station Ibadan. Ogbomoso climate data sourced from Nigeria Meteorological Station, International Airport Ilorin, Kwara State. RH - Relative Humidity; Max - Maximum; Min - Minimum; Temp - Temperature

Soil samples were collected in both fields at a depth of $0-15 \mathrm{~cm}$ for physical and chemical analysis. The samples were bulked to form a composite sample from which a representative sample was taken which was air-dried and crushed. The soil at Ogbomoso belongs to the order Alfisol (Smyth and Montgomery, 1962) derived from finegrained gnesis. The soil is moderately drained, ferruginous soil with a sandy loam texture.

Soil samples were taken randomly prior to planting to assess the nutrient status of the soil before planting in both locations. The textural class of the soils is sandy loam, but the clay content of Ogbomoso soil is slightly higher than at Ibadan (Table 2). The field was ploughed followed by harrowing. The field was marked out to give a plot size of $3.5 \mathrm{~m} \times 1.4 \mathrm{~m}\left(4.9 \mathrm{~m}^{2}\right)$ with $1 \mathrm{~m}$ between plots and $1 \mathrm{~m}$ between replicates. Twenty-eight accessions of grain amaranth sourced from the North Central Regional Plant Introduction Station (NCRPIS) of the United States National Plant Germplasm System by NIHORT, Ibadan, Nigeria were used as treatments for the trials (Table 3). The experiment was laid out in a randomized complete block design replicated three times. The total experimental area was $66.5 \mathrm{~m} \times 12.5 \mathrm{~m}\left(831.25 \mathrm{~m}^{2}\right)$.

Table 2: Physico-chemical characteristics of soil of the experimental sites

\begin{tabular}{lcc}
\hline Soil properties 0-15 cm depth & \multicolumn{2}{c}{2013} \\
\cline { 2 - 3 } & Ibadan & Ogbomoso \\
\hline Chemical properties & 5.80 & 5.80 \\
$\mathrm{pH}\left(\mathrm{H}_{2} \mathrm{O}\right)$ & 3.84 & 3.23 \\
Organic carbon $\left(\mathrm{g} \mathrm{kg}^{-1}\right)$ & 0.30 & 0.28 \\
Total N $\left(\mathrm{g} \mathrm{kg}^{-1}\right)$ & 3.80 & 6.00 \\
Available P $\left(\mathrm{g} \mathrm{kg}^{-1}\right)$ & 0.34 & 0.31 \\
Ex. K $\left(\mathrm{cmol} \mathrm{kg}^{-1}\right)$ & 0.26 & 0.26 \\
Ex. Na $\left(\mathrm{cmol} \mathrm{kg}^{-1}\right)$ & 3.11 & 3.42 \\
Ex. Ca $\left(\mathrm{cmol} \mathrm{kg}^{-1}\right)$ & 0.58 & 0.7 \\
Ex. Mg $\left(\mathrm{cmol} \mathrm{kg}^{-1}\right)$ & 0.28 & 0.08 \\
Ex. acidity $\left(\mathrm{cmol} \mathrm{kg}^{-1}\right)$ & 5.17 & 5.20 \\
CEC $(\mathrm{cmol} \mathrm{kg}$ & \\
Physical properties $\left(\mathrm{g} \mathrm{kg}^{-1}\right)$ & & \\
Sand & 868 & 860 \\
Clay & 12 & 20 \\
Silt & 120 & 120 \\
Textural class & Sandy loam & Sandy loam \\
\hline
\end{tabular}

Table 3: Passport data of grain amaranth accessions used for the study

\begin{tabular}{|c|c|c|c|}
\hline & $\begin{array}{l}\text { Accession } \\
\text { number }\end{array}$ & Origin/Source & Seed colour \\
\hline \multicolumn{4}{|c|}{ A AmaranthusCaudatus } \\
\hline 1 & RRC711 & Peru,Cuzco & $\begin{array}{l}\text { Golden, } \\
\text { brown, black }\end{array}$ \\
\hline 2 & $86-12$ & India,Uttar Pradesh & Cream \\
\hline 3 & RRC11 & India & Cream \\
\hline 4 & RRC1392 & Argentina & Cream \\
\hline 5 & MaliChua & India & Pink \\
\hline 6 & $74-43$ & India,Gujarat & Cream \\
\hline 7 & LSK267 & Peru & Cream, pink \\
\hline 8 & RRC551 & Argentina & Cream \\
\hline 9 & Quinoa & Argentina & Cream \\
\hline 10 & Coime & Bolivia, Tarija & Cream, pink \\
\hline 11 & RRC8 & Napal & Cream \\
\hline 12 & RRC125 & Sweden ,Malmohus & Cream \\
\hline 13 & RRC399 & Sweden, Malmohus & Cream \\
\hline 14 & DB2001949 & U.S.A, Iowa & Cream \\
\hline 15 & RRC1395 & Pakistan, Azad Kashmir & Black \\
\hline 16 & 108U22 & India, Himachal Pradesh & Cream \\
\hline 17 & RRC880 & Peru Cuzco & Cream, black \\
\hline 18 & RRC882 & Peru Cuzco & Black \\
\hline 19 & RRC889 & Peru, Cuzco & Black \\
\hline 20 & RRC1351 & Napal & Cream \\
\hline \multicolumn{4}{|c|}{ B Amaranthuscruentus } \\
\hline 21 & RRC 1041 & Mexico & Cream \\
\hline 22 & HH 100 & Mexico & Cream, black \\
\hline 23 & Y-004-W & U.S.A, Iowa & Cream \\
\hline \multicolumn{4}{|c|}{ C Amaranthushybridus } \\
\hline 25 & Quihuicha & Peru & Black \\
\hline 26 & No.22 & Mexico, Sonora & $\begin{array}{l}\text { Golden, } \\
\text { cream,brown }\end{array}$ \\
\hline $\mathrm{D}$ & \multicolumn{3}{|c|}{ Amaranthushypochondriacus } \\
\hline 27 & RRC K125 & U.S.A, Pennsylvana & Cream,black \\
\hline 28 & RRC 383 & U.S.A, California & Brown \\
\hline
\end{tabular}


The seeds were sown directly on the field at a spacing of $50 \mathrm{~cm} \times 35 \mathrm{~cm}$ after which thinning was done at 2 weeks after sowing (WAS) giving rise to 40 plants per plot, corresponding to 57,142 plants per hectare. Manual weeding using hoe was carried out whenever weeds were noticed in and around the plots. Data collection from 10 central plants started 6 WAS till maturity at 12 WAS. The following growth and yield parameters were assessed:

- Inflorescence length $(\mathrm{cm})$ : This was measured with meter rule starting from the last node on the base up to the tip of the inflorescence.

- Inflorescence weight (g): Mature inflorescence was harvested and weighed before seed removal.

- 1000-grain weight (g): a thousand grains were counted per accession and weighed.

- Grain yield: the inflorescence was harvested when mature to recover the grains.

Grain production efficiency was computed according to Ogunbodede and Ogunremi (1986) thus:

$$
\mathrm{GPE}=\frac{\text { grainweight } / \text { plant }(\mathrm{g})}{\text { Inflorescenceweight / plant }(\mathrm{g})} \times 100
$$

Data collected were subjected to analysis of variance (ANOVA) using SAS (2009) software to establish significant effects. Least significant difference was used to separate the means at $5 \%$ probability level. The yield parameters were analyzed by numerical taxonomic technique using the procedure for single linkage cluster analysis (SLCA) to show the relationship among the accessions which were employed to summarize the position of accession on a dendogram (Sneath and Sokal, 1973). Pearson moment correlation was done to determine the level of association between the yield parameters.

\section{RESULTS}

Grain Yield and Yield Components of 28 Accessions of Grain Amaranth in Two Locations There were significant differences in the length of inflorescence among the grain amaranth accessions (Table 4). The longest inflorescence was produced on RRC551 $(27.9 \mathrm{~cm})$ and was followed by accession $86-12(26.73 \mathrm{~cm})$. They were not significantly different from Quinoa $(25.2 \mathrm{~cm}) \mathrm{RRC} 8(23.07 \mathrm{~cm})$ and RRC880 $(23.9 \mathrm{~cm})$, while the shortest length was obtained from RRC1392 $(4.1 \mathrm{~cm})$.

Table 4: Grain yield and yield components of 28 accessions of grain amaranth accessions as affected in two locations.

\begin{tabular}{|c|c|c|c|c|c|}
\hline Accession & $\begin{array}{l}\text { Inflorescence } \\
\text { length }(\mathrm{cm})\end{array}$ & $\begin{array}{c}\text { Inflorescence weight } \\
(\mathrm{g})\end{array}$ & $\begin{array}{c}\text { Grain yield } \\
\left(\mathrm{t} \mathrm{ha}^{-1}\right)\end{array}$ & $\begin{array}{c}1000 \text { Grain Weight } \\
(\mathrm{g})\end{array}$ & $\begin{array}{l}\text { GPE } \\
(\%)\end{array}$ \\
\hline RRC711 & 9.83 & 94.60 & 0.2 & 0.80 & 7.14 \\
\hline $86-12$ & 26.73 & 99.40 & 0.53 & 1.24 & 12.36 \\
\hline RRC11 & 19.07 & 123.75 & 0.16 & 0.71 & 2.21 \\
\hline RRC1392 & 4.05 & 29.80 & 0.32 & 0.98 & 19.30 \\
\hline MaliChua & 9.15 & 43.08 & 0.16 & 0.83 & 4.61 \\
\hline $74-43$ & 13.35 & 242.95 & 1.71 & 0.86 & 34.13 \\
\hline LSK267 & 20.88 & 202.33 & 1.21 & 0.89 & 11.24 \\
\hline RRC551 & 27.93 & 93.52 & 1.25 & 0.97 & 39.67 \\
\hline Quinoa & 25.23 & 31.47 & 0.87 & 0.84 & 36.78 \\
\hline Coime & 8.65 & 33.22 & 0.7 & 0.76 & 27.13 \\
\hline RRC8 & 23.07 & 32.81 & 1.4 & 0.83 & 44.49 \\
\hline RRC125 & 7.40 & 28.75 & 0.4 & 0.86 & 17.71 \\
\hline RRC399 & 6.94 & 31.42 & 1.78 & 1.10 & 70.25 \\
\hline DB2001949 & 14.82 & 25.59 & 0.27 & 0.99 & 12.69 \\
\hline RRC 1395 & 15.37 & 27.76 & 0.23 & 0.70 & 10.27 \\
\hline 108U22 & 9.02 & 22.26 & 0.26 & 0.71 & 15.83 \\
\hline RRC880 & 23.93 & 31.26 & 0.35 & 0.76 & 15.39 \\
\hline RRC882 & 10.28 & 63.10 & 0.4 & 0.84 & 8.81 \\
\hline RRC889 & 14.26 & 54.87 & 0.47 & 0.79 & 11.51 \\
\hline RRC1351 & 11.78 & 55.50 & 1.89 & 1.06 & 44.41 \\
\hline RRC1041 & 10.25 & 55.32 & 0.36 & 0.87 & 7.85 \\
\hline HH100 & 17.42 & 53.07 & 0.37 & 0.74 & 8.84 \\
\hline Y-004-W & 8.05 & 40.10 & 0.51 & 0.61 & 17.28 \\
\hline RRC19A & 12.61 & 21.24 & 0.27 & 0.60 & 18.53 \\
\hline Quihuicha & 5.87 & 24.24 & 0.2 & 0.58 & 14.72 \\
\hline No.22 & 13.37 & 22.19 & 0.56 & 0.66 & 33.01 \\
\hline RRCK125 & 17.20 & 24.46 & 0.34 & 0.75 & 14.18 \\
\hline RRC383 & 15.82 & 39.62 & 0.2 & 0.38 & 8.50 \\
\hline \multicolumn{6}{|l|}{ Location } \\
\hline Ibadan & 14.63 & 75.17 & 0.66 & 0.80 & 22.58 \\
\hline Ogbomoso & 14.10 & 42.52 & 0.57 & 0.82 & 18.79 \\
\hline \multicolumn{6}{|l|}{$\mathrm{LSD}_{0.05}$} \\
\hline Accession & 4.95 & 59.03 & 0.11 & 0.22 & 9.58 \\
\hline Location & 1.32 & 15.78 & 0.73 & 0.06 & 2.56 \\
\hline Location $\times$ Accession & $* *$ & $* *$ & $* *$ & $* *$ & $* *$ \\
\hline
\end{tabular}

WAS - week after sowing, LSD $_{0.05}$ - Least significant different at $5 \%$ probability, GPE - Grain Production Efficiency,

*Significant at $p=0.05, * *$ Significant at $p=0.01$ 
Accession 74-43 had the highest inflorescence weight of $243.0 \mathrm{~g} / \mathrm{plant}$ and was not significantly different from LSK267 (202.3 g/plant) while the lowest weight was recorded on accession Quihuicha (21.24 g/plant). Accession 86-12 had the highest 1000 -grain weight among other accessions (1.24 $\mathrm{g})$, though not significantly $(p<0.05)$ different from RRC399 (1.1 g) and RRC1351 (1.1 g), while RRC383 had the lowest 1000-grain weight of $0.4 \mathrm{~g}$ which was similar with Quihuicha (0.6 g). RRC399 had the highest grain production efficiency among other accessions (70.3\%) and the lowest was obtained from RRC11 which had $2.2 \%$ (Table 4 ).

There were no significant $(p<0.05)$ differences in inflorescence length between the two locations (Ibadan and Ogbomoso), but inflorescence produced in Ibadan $(75.2 \mathrm{~g} /$ plant $)$ significantly $(p<0.05)$ weighed more than that of Ogbomoso (42.5 g/plant) (Table 4). Higher inflorescence weight obtained in Ibadan resulted in significantly $(p<0.05)$ higher grain yield $\left(0.66 \mathrm{t} \mathrm{ha}^{-1}\right)$ compared to Ogbomoso $\left(0.57 \mathrm{t} \mathrm{ha}^{-1}\right)$ (Table 4). The 1000-grain weight obtained at Ogbomoso (0.82 g) was not significantly $(p>0.05)$ different from that at Ibadan $(0.80 \mathrm{~g})$ (Table 4$)$. Grain production efficiency was higher in grain amaranth accessions planted in Ibadan (22.6\%) than that in Ogbomoso (18.8\%). The location by accession interaction was highly significant $(p<0.05)$ in terms of the inflorescence length and weight, grain yield, thousand grain weight and grain production efficiency (Table 4).

\section{Effect of Accession by Location on Yield} Components of Grain Amaranth

The effects of the accessions planted in the two locations on the yield parameter of grain amaranth accessions are presented in Table 5. The longest inflorescence was recorded in LSK267 at Ogbomoso $(35.4 \mathrm{~cm})$ though not significantly different from RRC551 planted in Ogbomoso and accession 86-12 planted in Ibadan (30.7 and $29.0 \mathrm{~cm}$, respectively), while lowest was obtained from RRC1392 at Ogbomoso $(2.9 \mathrm{~cm})$. Accession $74-43$ planted in Ibadan had the highest inflorescence weight (451.9 $\mathrm{g} /$ plant) and was significantly $(p<0.05)$ different from accession No.22 in the same location that had the lowest (14.2 g/plant) among all the accessions in both locations. Accession 86-12 planted in Ogbomoso produced the highest 1000-grain weight per plant (1.6 g), while the lowest was obtained from RRC383 in the same location (Ogbomoso) with $0.3 \mathrm{~g}$ (Table 5). Grain production efficiency was highest in RRC399 planted in Ibadan (76.6\%) and was not significantly $(p<0.05)$ different from the same accession (RRC399) planted in Ogbomoso (63.9\%) and Accession 74-43 (63.3\%) also in Ogbomoso, while the lowest was from RRC711 $(1.57 \%)$ planted in Ibadan and was not significantly $(p<0.05)$ different from RRC11 $(1.36 \%)$ also from Ibadan, RRC711 (3.06\%), MaliChua (3.21\%) and Quihuicha (2.49\%) in Ogbomoso (Table 5).

\section{Effect of Accessions by Location on Grain Yield of Amaranth}

The grain yield was highest in RRC1351 planted in Ibadan $\left(1.67 \mathrm{t} \mathrm{ha}^{-1}\right)$ though not significantly $(p<$ $0.05)$ different from LSK267 in the same location (1.91 $\left.\mathrm{t} \mathrm{ha}^{-1}\right)$, while the lowest was obtained in accession Quihuicha planted in Ogbomoso with $0.07 \mathrm{t} \mathrm{ha}^{-1}$ (Figure 1). The best five accessions that were stable across locations and outperformed others were Accession 74-43 with grain yields of 1.67 and $1.74 \mathrm{t} \mathrm{ha}^{-1}$ in Ibadan and Ogbomoso, respectively; RRC1351 with grain yield of 1.98 and $1.81 \mathrm{t} \mathrm{ha}^{-1}$ in Ibadan and Ogbomoso, respectively; RC399 with grain yields of 1.82 and $1.75 \mathrm{t} \mathrm{ha}^{-1}$ in Ibadan and Ogbomoso, respectively; RRC8 with grain yields of 1.57 and $1.22 \mathrm{t} \mathrm{ha}^{-1}$ in Ibadan and Ogbomoso, respectively; and RRC551 with grain yields of 1.50 and $1.00 \mathrm{t} \mathrm{ha}^{-1}$ in Ibadan and Ogbomoso, respectively (Figure 1). The highest grain yield was obtained from RRC1351 (1.89 t $\mathrm{ha}^{-1}$ ), while the lowest yield was obtained from $\operatorname{RRC11}\left(0.16 \mathrm{tha}^{-1}\right)$, as seen in Table 4.

\section{Cluster Analysis of 28 Accessions of Amaranth}

In this study, cluster analysis revealed four groups of the accessions at $75 \%$ similarity level based on yield indices (Figure 2). The dendogram based on the single linkage cluster analysis is shown in Figure 2. Group 1 had Accession 74-43 which had inflorescence length of $13.35 \mathrm{~cm}$, inflorescence weight of $242.95 \mathrm{~g}$, grain production efficiency of $34.13 \%$ and grain yield $1.7 \mathrm{tha}^{-1}$, with distinguishing characteristics. Group 2 comprised one accession (Accession RRC8) which had inflorescence length of $23.67 \mathrm{~cm}$, inflorescence weight of $32.81 \mathrm{~g}$; grain production efficiency of $54.49 \%$ and grain yield of $1.57 \mathrm{t} \mathrm{ha}^{-1}$. Group 3 comprised one accession (Accession LSK267) which had inflorescence length of $20.88 \mathrm{~cm}$, inflorescence weight of 202.33 $\mathrm{g}$, grain production efficiency of $11.24 \%$ and grain yield of $1.21 \mathrm{t} \mathrm{ha}^{-1}$. Group 4 had 25 out of 28 accessions which included Quinoa, RRC711, RRC551, RRC11, Coime, RRC1395, 86-12, RRC399, RRC125, MaliChua, among others. This implies that these 25 accessions of grain amaranth had similarity among them.

\section{Correlation between Grain Yield and Yield Components of Amaranth}

There was correlation between inflorescence length and the weight produced, and this inflorescence length was highly correlated with fresh and dry shoot and root weight of Amaranth. Inflorescence weight was highly positively correlated with seed (grain) and was negatively correlated with the grain production efficiency (Table 6). Grain weight, 1000-grain weight and grain production efficiency were all positively correlated $(r=0.01)$. Grain production efficiency and 1000-grain weight were highly positively correlated (Table 6). 
Table 5: Interaction effect of accession x location on yield components of grain amaranth in Ibadan and Ogbomoso

\begin{tabular}{|c|c|c|c|c|c|c|c|c|c|c|c|c|}
\hline \multirow[t]{2}{*}{ Accession } & \multicolumn{3}{|c|}{ Inflorescence length $(\mathrm{cm})$} & \multicolumn{3}{|c|}{ Inflorescence weight (g) } & \multicolumn{3}{|c|}{1000 Grain Weight $(\mathrm{g})$} & \multicolumn{3}{|c|}{ Grain Production Efficiency (\%) } \\
\hline & $\begin{array}{l}\text { Iba- } \\
\text { dan }\end{array}$ & $\begin{array}{l}\text { Ogbo- } \\
\text { moso }\end{array}$ & mean & $\begin{array}{l}\text { Iba- } \\
\text { dan }\end{array}$ & $\begin{array}{l}\text { Ogbo- } \\
\text { moso }\end{array}$ & mean & $\begin{array}{l}\text { Iba- } \\
\text { dan }\end{array}$ & $\begin{array}{l}\text { Ogbo- } \\
\text { moso }\end{array}$ & mean & $\begin{array}{l}\text { Iba- } \\
\text { dan }\end{array}$ & $\begin{array}{l}\text { Ogbo- } \\
\text { moso }\end{array}$ & mean \\
\hline RRC711 & 10.17 & 9.50 & 9.84 & 165.23 & 23.97 & 94.60 & 0.96 & 0.64 & 0.80 & 1.57 & 13.26 & 7.42 \\
\hline $86-12$ & 29.00 & 24.45 & 26.73 & 149.70 & 49.09 & 99.40 & 0.87 & 1.61 & 1.24 & 5.51 & 19.20 & 12.36 \\
\hline RRC11 & 20.47 & 17.67 & 19.07 & 199.30 & 48.19 & 123.75 & 0.67 & 0.76 & 0.72 & 1.36 & 3.06 & 2.21 \\
\hline RRC1392 & 5.20 & 2.90 & 4.05 & 26.33 & 33.27 & 29.80 & 0.76 & 1.19 & 0.98 & 25.52 & 13.08 & 19.30 \\
\hline MaliChua & 8.90 & 9.40 & 9.15 & 46.80 & 39.37 & 43.09 & 0.93 & 0.72 & 0.83 & 6.00 & 3.21 & 4.61 \\
\hline $74-43$ & 18.34 & 8.37 & 13.36 & 451.87 & 34.03 & 242.95 & 0.83 & 0.89 & 0.86 & 4.92 & 63.34 & 34.13 \\
\hline LSK267 & 6.37 & 35.40 & 20.89 & 326.47 & 78.20 & 202.34 & 1.00 & 0.79 & 0.90 & 14.62 & 7.87 & 11.25 \\
\hline RRC551 & 25.13 & 30.73 & 27.93 & 148.35 & 38.68 & 93.52 & 1.10 & 0.84 & 0.97 & 42.10 & 37.24 & 39.67 \\
\hline Quinoa & 25.00 & 25.47 & 25.24 & 21.26 & 41.71 & 31.49 & 0.89 & 0.79 & 0.84 & 44.49 & 29.07 & 36.78 \\
\hline Coime & 9.52 & 7.77 & 8.65 & 24.61 & 41.82 & 33.22 & 0.73 & 0.80 & 0.77 & 31.95 & 22.31 & 27.13 \\
\hline RRC8 & 21.70 & 24.43 & 23.07 & 33.15 & 32.47 & 32.81 & 0.84 & 0.81 & 0.83 & 63.94 & 48.04 & 55.99 \\
\hline RRC125 & 7.70 & 7.10 & 7.40 & 23.87 & 33.63 & 28.75 & 0.82 & 0.90 & 0.86 & 18.43 & 16.99 & 17.71 \\
\hline RRC399 & 7.94 & 5.93 & 6.94 & 29.38 & 33.47 & 31.43 & 1.00 & 1.20 & 1.10 & 76.64 & 63.85 & 70.25 \\
\hline DB2001949 & 14.33 & 15.30 & 14.82 & 23.92 & 27.26 & 25.59 & 0.94 & 1.04 & 0.99 & 12.23 & 13.15 & 12.69 \\
\hline RRC1395 & 17.10 & 13.63 & 15.37 & 24.58 & 30.95 & 27.77 & 0.67 & 0.73 & 0.70 & 11.83 & 8.72 & 10.28 \\
\hline $108 \mathrm{U} 22$ & 11.57 & 6.47 & 9.02 & 17.64 & 26.88 & 22.26 & 0.66 & 0.76 & 0.71 & 21.21 & 10.44 & 15.83 \\
\hline RRC880 & 23.73 & 24.13 & 23.93 & 23.83 & 38.68 & 31.26 & 0.76 & 0.75 & 0.76 & 20.86 & 9.92 & 15.39 \\
\hline RRC882 & 10.53 & 10.03 & 10.28 & 53.87 & 72.33 & 63.10 & 0.86 & 0.83 & 0.85 & 10.62 & 7.00 & 8.81 \\
\hline RRC889 & 14.71 & 13.80 & 14.26 & 44.95 & 64.80 & 54.88 & 0.75 & 0.82 & 0.79 & 12.27 & 10.74 & 11.51 \\
\hline RRC1351 & 14.13 & 9.43 & 11.78 & 46.29 & 64.72 & 55.51 & 1.05 & 1.06 & 1.06 & 54.10 & 34.72 & 44.41 \\
\hline RRC1041 & 12.93 & 7.57 & 10.25 & 45.13 & 65.50 & 55.32 & 0.60 & 1.14 & 0.87 & 7.91 & 7.79 & 7.85 \\
\hline HH100 & 17.33 & 17.50 & 17.42 & 44.83 & 61.31 & 53.07 & 0.76 & 0.73 & 0.75 & 10.11 & 7.56 & 8.84 \\
\hline Y-004-W & 12.67 & 3.43 & 8.05 & 32.98 & 47.21 & 40.10 & 0.73 & 0.48 & 0.61 & 21.10 & 13.46 & 17.28 \\
\hline RRC19A & 5.11 & 20.10 & 12.61 & 21.62 & 20.85 & 21.24 & 0.52 & 0.68 & 0.60 & 16.51 & 20.55 & 18.53 \\
\hline Quihuicha & 5.90 & 5.83 & 5.87 & 14.88 & 33.60 & 24.24 & 0.73 & 0.43 & 0.58 & 26.94 & 2.49 & 14.72 \\
\hline No. 22 & 19.74 & 7.00 & 13.37 & 14.21 & 30.17 & 22.19 & 0.66 & 0.67 & 0.67 & 38.69 & 27.33 & 33.01 \\
\hline RRCK125 & 17.07 & 17.33 & 17.20 & 16.25 & 32.27 & 24.26 & 0.88 & 0.62 & 0.75 & 20.40 & 7.95 & 14.18 \\
\hline RRC383 & 17.47 & 14.17 & 15.82 & 33.43 & 45.83 & 39.63 & 0.42 & 0.33 & 0.38 & 13.28 & 3.72 & 8.50 \\
\hline $\operatorname{LSD}_{0.05}$ & \multicolumn{2}{|c|}{6.99} & & \multicolumn{2}{|c|}{83.27} & & \multicolumn{2}{|c|}{0.32} & & \multicolumn{2}{|c|}{13.55} & \\
\hline
\end{tabular}

LSD $_{0.05}$ - least significant different at $5 \%$ probability, WAS - week after sowing

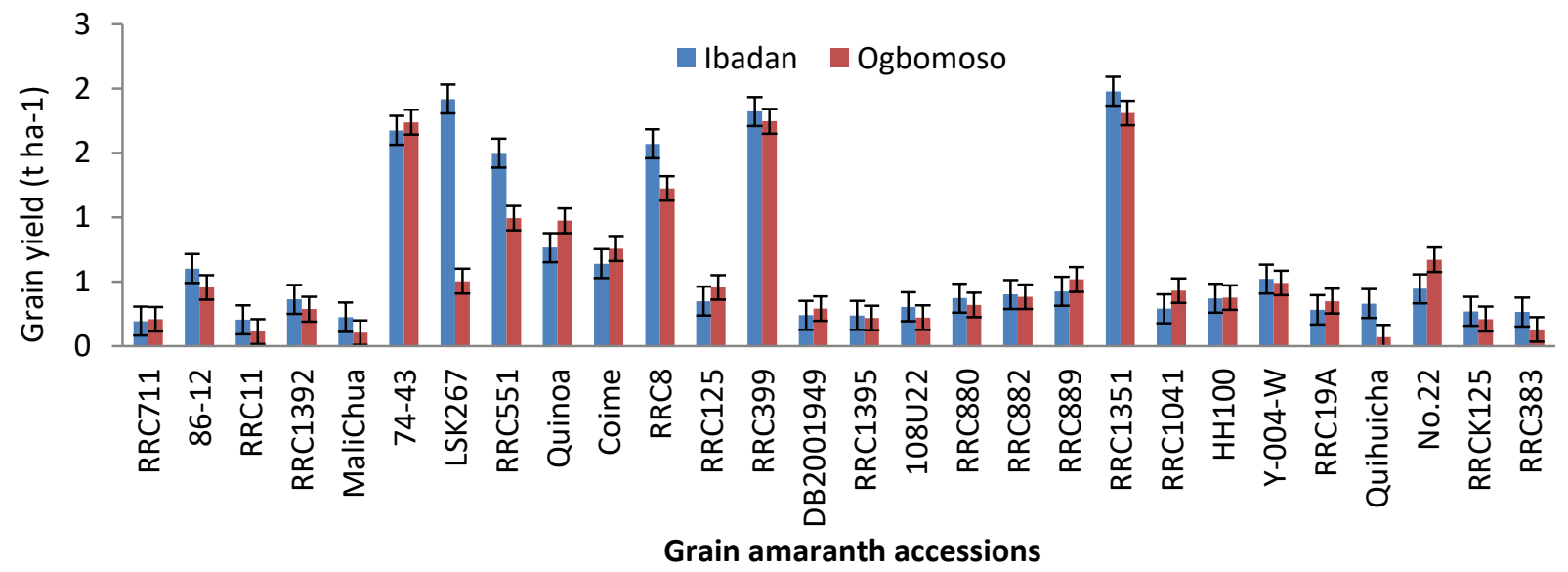

Figure 1: interaction between accessions and locations on grain yield

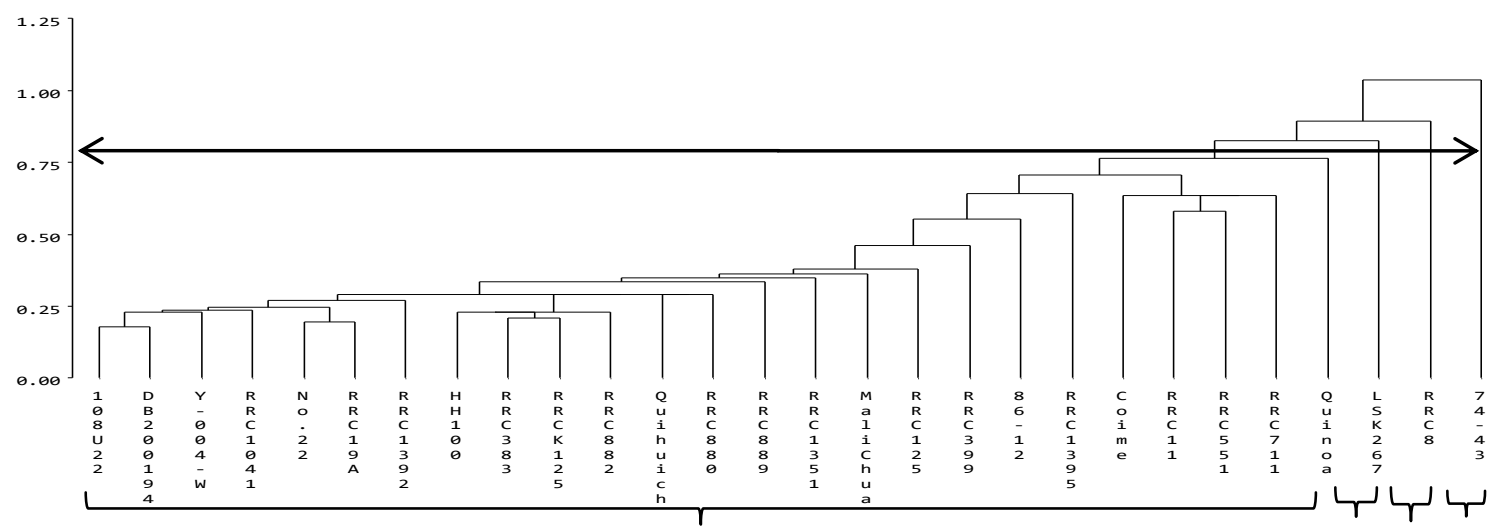

Figure 2: Dendogram resulting from Ward method cluster analysis of 28 accessions of grain amaranth Key: I - Group 1, II - Group 2, III - Group 3, IV - Group 4 


\section{DISCUSSION}

In order to maintain, evaluate and utilize germplasm effectively in hybridization programme for development of high-yielding grain accessions, it is important to assess the extent of genetic morphological diversity existing among grain amaranth accessions. Smith and Smith (1989) considered morphological characterization as an important first step in description and classification of crop germplasm because a breeding programme mainly depends upon the magnitude of genetic variability (Smith et al., 1991).

A considerable level of variability for qualitative characters such as leaf pigmentation, petiole pigmentation, inflorescence colour, inflorescence density index, terminal inflorescence attitude, terminal inflorescence shape, and seed colour was observed in the newly introduced 28 accessions which were from 24 countries. This variability may be related strongly to the diverse geographical origins of the newly introduced 28 accessions. A strong relationship of diversity and geographical origin has been reported in crops such as vegetable amaranth (Shukla et al., 2010), oats (Rezai and Frey, 1990), maize (Alika et al., 1993) and bambara groundnut (Ntundu et al., 2006). Laghetti et al. (1998) advocated that maximum genetic conservation would be achieved by sampling populations from as many environments as possible. Some of the accessions possessed good genes for more than one character and hence could be utilized directly or included in hybrid programme for varietal development (Ghafoor et al., 2001).

Variations in growth, biomass and grain yield of the accessions were attributed to variations in the origins of the plant since the 28 accessions were from different countries. The adaptability of the different accessions to Nigeria climatic condition was because of inherent genetic variation leading to high chances of survival. Myers and Robert (1998) and Liu and Stuitzel (2002) noted that amaranth has a combination of traits responsible for its capacity to adapt to unfavourable growing conditions, such as low availability of nutrients and a wide range of soil moisture and temperature.

Gruben (2004) reported similarly that for the conventional accessions, there was genotypic variation in seed survival and other parameters taken. Research has shown that grain amaranth yields are extremely variable depending upon species and genotype, site, soil and weather conditions, growing season and agronomic practices. Grain yields from 1000 to $3000 \mathrm{~kg} \mathrm{ha}^{-1}$ have been achieved in the United States and in several countries of Northern Europe (Pospisil et al., 2006), $1800-2300 \mathrm{~kg} \mathrm{ha}^{-1}$ and exceptionally $4500 \mathrm{~kg} \mathrm{ha}^{-1}$ in Argentina (Tosi and Ré, 2003), $5000 \mathrm{~kg} \mathrm{ha}^{-1}$ or even more under intensive cultivation in China (Wu et al., 2000) and 1200-6700 $\mathrm{kg} \mathrm{ha}^{-1}$ in southern Italy (Alba et al., 1997; Lovelliet al., 2005).
This result corroborates Hoheisel (1998) that crop production has been largely influenced by environmental factors that affect all the processes from metabolism to gene expression during plant growth and development. Also, Yao et al. (2008) noted that differences in the agronomic parameters could be adduced to variety, environmental and cultural practices. Research has shown that both abiotic and biotic factors cause variations in growth and yields of crops (Ramegowda and SenthilKumar, 2015; Prasch and Sonnewald, 2015). All the accessions had good yield biomass in both locations for grain amaranth. These results agree with Grubben (2004) that vegetable amaranths grow well at day temperatures above $25^{\circ} \mathrm{C}$ and night temperatures not lower than $15^{\circ} \mathrm{C}$. Any efforts towards increasing the acidic $\mathrm{pH}$ of the soils occurring in the locations of the present study to near-neutral values may further improve the yield of the crop in those locations (Okorie et al., 2017).

\section{CONCLUSION}

Variability existed among the accessions of grain amaranth evaluated for yield parameters. There were significant differences $(p<0.05)$ in the grain yield of the accessions. Out of the 28 accessions planted, accession 74-43, RRC1351, RRC399, RRC8 and RRC551 had significantly higher yields in Ibadan and Ogbomoso. These accessions are all Amaranthus Caudatus spp. Accessions 74-43 (India), RRC1351 (Nepal), RRC399 (Sweden), RRC8 (Nepal) and RRC551 (Argentina) from different countries adapt well in the tropical region of Africa. The top high-yielding accessions were RRC1351, RRC399, 74-43, RRC8 and RRC551. Furthermore, irrespective of the accessions, the two agro-ecological zones are suitable for high grain yield of grain amaranth but Ogbomoso gave higher yields than Ibadan. For increases in grain yield of grain amaranth, Ogbomoso (derived savanna zone) is preferred to Ibadan (forest-savanna transition zone) as a growing environment for the crop. This can be attributed to better adaptation of the accessions in low humidity. Growing any of the selected five accessions including 74-43, RRC1351, RRC399, RRC8 and RRC551 in either of the two locations can give grain yield in excess of $1.00 \mathrm{tha}^{-1}$.

\section{REFERENCES}

Alba E., Polignano G.B., and Notarnicola L. (1997). Yield stability in a set of Amaranth entries in Southern Italy. Italian Journal Agronomy, 1, 65-71

Alika J.E., Aken'ova M.E. and Fatokun C.A. (1993). Variation among maize (Zea mays L.) accessions of Bendel State, Nigeria: multivariate analysis of agronomic data. Euphytica, 66, 65-71

Campbell T.A. and Abbott J.A. (1982).Field evaluation of vegetable amaranth (Amaranthus spp.). Horticultural Science, 17, 407-409 
Dulloo E. and Engles J.M.M. (2003). Genebank standards and quality assurance. In: A Guide to Effective Management of Germplasm Collections, Engles J.M.M and Visser L. (eds.): IPGRI Handbooks for Genebanks No. 6. Rome, Italy: International Plant Genetic Resources Institutepp 140-146

Gamel T.H., Linssen J.P., Alink G.M., Massallem A.S. and Shekib L.A. (2004). Nutritional study of raw and popped seed proteins of Amaranth Caudatus L. $a d b$. Amaranth Cruentus L. Journal of the Science of Food \& Agriculture, 84, 1153-1158

Ghafoor A., Sharifb A., Ahmada Z., Zahidc M.A. and Rabbania M.A. (2001).Genetic diversity in blackgram (Vignamungo L. Hepper). Field Crops Research, 69, 183-190

Grubben G.J.H. (2004). Amaranthus cruentus L. In: Grubben G.J.H. and Denton O.A. (eds), Plant Resources of Tropical Africa 2: Vegetables. PROTA Foundation, Wageningen. Buckkuys Publishers, Leiden/CTA, Wageningen, The Netherlands p. 667

Hoheisel D., Nitz T., Franke H., Wegener J., Hakvoort A., Tilling T. and Galla, H.J. (1998). Hydrocortisone reinforces the blood brain barrier properties in a serum-free cell-culture system. Biochem. Biophys. Res. Commun., 244, 312-316

Jacobsen S.E., Ruiz E., Mujica A., Christiansen J.L. and Ortiz R. (2001). Evaluación de Accessiones de Quinuapara la Tolerancia a Salinidad. In: Jacobsen S.E. and Portillo Z. (eds.) Memorias, Primer Taller Internacional sobre Quinua - Recursos Geneticos y Sistemas de Producción (10-14 May 1999), Universidad Nacional Agraria La Molina, Lima, Peru

Kurlovich B.S. (1998). Species and intraspecific diversity of white, blue and yellow lupins. Plant Genetic Research Newsletter, 115, 23-32

Liu F. and Stutzel H. (2002). Leaf expansion, stomatal conductance and transpiration of vegetable amaranth (Amaranthus sp.) in response to soil drying. Journal Amer. Soc. Hort. Sci., 5, 878-883

Lovelli S., Pizza S., Caponio T., Gherbin P. and Perniola M. (2005).Analisi di crescita e valutazioneagronomica di alcunespecieerbacee a bassotenore di glutine. In: Proceedings of 34th Congress of the Italian Society of Agronomy, 20-22 Sep., Foggia, Italy, pp. 298-299

Mnkeni A.P., Mosika P. and Maphaha M. (2007). Nutritional quality of vegetables and seeds from different accessions of Amaranthus in South Africa. South Africa Journal of Biotechnology, 33, 369-376

Myers R.L. and Robert L. (1998). Grain Amaranth: A Lost Crop of the Americas. Thomas Jefferson Agricultural Institute, Columbia, MO, USA, 65203

Ntundu W.H., Shillah S.A., Marandu W.Y.F. and Christiansen J.L. (2006). Morphological diversity of bambara groundnut (Vigna subterranean (L.) Verdc.) landraces in Tanzania. Genetic Resources and Crop Evolution (GRACE), 53, 367-368

Ogunbodede B.A. and Ogunremi E.A. (1986). Estimation of sesame (Sesamum indicum L.) yield parameters. Nigerian Journal of Agronomy, 1, 9-13

Okorie E.E., Obalum S.E. and Singh L. (2017). The potential of fermented cottonseed oil-mill effluent as inexpensive biofertilizers and its agronomic evaluation on medium-textured tropical soil. Int. Journal of Recycling of Organic Wastes in Agriculture, 6 (2), 117-124. DOI: 10.1007/s40093-017-0158-6
Oraegbunam C.J., Njoku O.M., Imoh O.N., Obalum S.E., Onyia V.N., Atugwu A.I. and Uchida Y. (2016). Agronomic performance and adaptability of three varieties of watermelon (Citrullus lanatus) on sandy loam soil in Derived Savanna. Agro-Science, 15 (3), 46-50

Pospisil A., Pospisil M., Varga B. and Svenjak Z. (2006). Grain yield and protein concentration of two amaranth species (Amaranthus spp.) as influenced by the nitrogen fertilization. European Journal of Agronomy, 25, 250-253

Prasch C.M. and Sonnewald U. (2015). Signaling events in plants: stress factors in combination change the picture. Environ. Exp. Bot., 114, 4-14

Ramegowda V. and Senthil-Kumar M. (2015). The interactive effects of simultaneous biotic and abiotic stresses on plants: mechanistic understanding from drought and pathogen combination. Journal of Plant Physiology, 176, 47-54

Rezai A. and Frey K.J. (1990). Multivariate analysis of variation among wild oat accessions - seed traits. Euphytica, 49, 111-119

SAS Institute (2009). Software statistical programme User's Guide: Statistics. SAS Institute, Incorporation, Cary, NC, USA

Shukla S., Bhargava A., Chatterjee A., Pandeya A.C. and Mishra B.K. (2010). Diversity in phenotypic and nutritional traits in vegetable amaranth (Amaranthus tricolor), a nutritionally underutilised crop. Journal of Science Food Agric., 90, 139-144

Smith J.S.C. and Smith O.S. (1989). The description and assessment of distances between inbred lines of maize: the utility of morphological, biochemical and genetic descriptors and a scheme for the testing of distinctiveness between inbred lines. Maydica, 34, 151-161

Smith S.E., Doss A.A. and Warburton M. (1991). Morphological and agronomic variation in North African and Arabian alfalfas. Crop Science, 31, 11591163

Smyth A.J. and Montgomery R.F. (1962). Soils and land use in Central Western Nigeria. Government Printer, Ibadan, Western Nigeria p. 85

Sneath P.H.A. and Sokal R.R. (1973). Numerical Taxonomy: The Principles and Practice of Numerical Classification. WF Freeman \& Co., San Francisco, $573 \mathrm{pp}$.

Tosi E.A. and Ré E. (2003). Amaranto. Su aplicación en la alimentaciónhumana. Aposgran, 2, 15-16

Vijayakumar B. (1980). Studies on Growth and Development of Certain Types of Amaranthtus (Amaranthus spp. L.) M.Sc. (Ag.) thesis, Tamil Nadu Agricultural University, Coimbatore, India, p. 115

Wu H.X., Sun M., Yue S.X., Sun H.L., Cai Y.Z., Huang R.H., Brenner D. and Corke H. (2000). Field evaluation of an Amaranthus genetic resource collection in China. Genetic Resources \& Crop Evolution, 1, 43-53

Yao Y., Liu Q., Liu Q. and Li X. (2008). LAI retrieval and uncertainty evaluations for typical row-planted crops at different growth stages. Remote Sensing of Environment, 1, 94-106 